\title{
Screening of the Antibiotic Resistant Environmental Bacteria Isolated from Selected Niches in and Around Kanchipuram Town, India
}

\author{
G. Suresh ${ }^{1 *}$, P. Raghu ${ }^{1}$, U. Prakash ${ }^{1}$, T. Chitrikha Suresh ${ }^{2}$, S. Kumaran ${ }^{1}$, \\ S. Bharathi ${ }^{1}$, K. Selvendiran ${ }^{1}$ and T. V. Poonguzhali ${ }^{2}$ \\ ${ }^{1}$ Department of Microbiology, Sri Sankara Arts \& Science College, Enathur, \\ Kanchipuram, Tamil Nadu, India \\ ${ }^{2}$ Department of Botany, Queen Mary's College, Chennai, Tamil Nadu, India \\ *Corresponding author
}

\section{A B S T R A C T}

\begin{tabular}{|l|}
\hline Ke y w o r d s \\
$\begin{array}{l}\text { Antibiotic resistance, } \\
\text { ESBL, Soil, Environment }\end{array}$ \\
\hline Article Info \\
\hline $\begin{array}{l}\text { Accepted: } \\
\text { 30 April } 2018 \\
\text { Available Online: } \\
\text { 10 June } 2018\end{array}$ \\
\hline
\end{tabular}

The aim of this study was to isolate and identify environmental bacteria from various soils in areas where human activities influence the soil microbiota and might exert a strong positive pressure to resistance development and spreading. Our results revealed that environmental bacteria with high antibiotic resistant level. All the gram positive bacterial isolates showed resistant against Penicillin G and Ampicillin. Out of 27 gram negative bacterial isolates, 23 organisms showed ESBL positive based on phenotypic characterization. Linking the environmental strains with clinic ones, promoted by human activities, might be a vital consideration. Our results indicate that, there is a need to embrace coordinated multi-locational approaches and interrelationships to track the emergence of resistance in different niches in soil and water versus the hospital environment.

\section{Introduction}

The emergence of antibiotic resistance (AR) is an outcome of a repertoire of factors in various environmental and clinical settings (Rizzo et al., 2013). The critical role of the environment in the development and dissemination of antibiotic resistance genes (ARGs) is fast being appreciated, unlike the time when all focus was on hospital-acquired AR. Antibiotics and ARGs may partly originate from environmental bacteria, and selection for them is closely connected with anthropogenic contamination with residual antibiotics (RAbs), to which exposure of pathogenic bacteria in the same environment occurs (Allen et al., 2010). Antimicrobial resistance (AMR) threatens the effective prevention and treatment of an ever-increasing range of infections caused by bacteria, parasites, viruses and fungi. AMR is an increasingly serious threat to global public health that requires action across all government sectors and society (Baquero et al., 2008).

Antimicrobial resistance happens when microorganisms (such as bacteria, fungi, viruses, and parasites) change when they are exposed to antimicrobial drugs (such as 
antibiotics, antifungals, antivirals, antimalarials, and anthelmintics). Microorganisms that develop antimicrobial resistance are sometimes referred to as "superbugs" (Adegoke et al., 2016). New resistance mechanisms are emerging and spreading globally, threatening our ability to treat common infectious diseases, resulting in prolonged illness, disability, and death. Antimicrobial resistant-microbes are found in people, animals, food, and the environment (in water, soil and air). They can spread between people and animals, and from person to person. Poor infection control, inadequate sanitary conditions and inappropriate foodhandling encourage the spread of antimicrobial resistance (WHO, 2016).

ESBLs are enzymes whose rates of hydrolysis of the extended-spectrum beta-lactam antibiotics such as ceftazidime, cefotaxime, oraztreonam are $>10 \%$ than that for benzyl penicillin. These are susceptible to inhibition by beta-lactam inhibitors such as clavulanic acid, tazobactam, or sulbactam but have no hydrolytic activity against cephamycins and carbapenems (Bush, 2013). Major ESBL are commonly expressed by many clinical isolates and are detected in many parts of the world whereas the minor types are rarely encountered or are restricted to certain geographical locations only. Currently, the three major ESBL types are TEM, SHV and CTX-M.

The present study was carried out to isolate and identify the aerobic bacterial pathogen from environmental samples from in and around Kanchipuram and to assess antimicrobial susceptibility pattern of the isolates by Kirby Bauer disc diffusion method as recommended by clinical and laboratory standards institute (CLSI) guidelines, to commonly used antibiotics and newer broad spectrum agents. Characterization of virulence factors in multi-drug resistant bacteria isolated environmental samples by phenotypic method was also performed in the present investigation.

\section{Materials and Methods}

\section{Sample collection}

Soil samples were collected from selected locations in and around Kanchipuram, Tamil Nadu, India. Locations were selected based on waste dumping sites in Kanchipuram. Totally, 6 samples were collected using sterile polythene bags and transported to laboratory within two hours. During sampling temperature of the soils were measured.

\section{Isolation and Identification of bacteria from collected soil samples}

Bacterial examinations of collected soil samples were done employing serial dilution technique. About $10 \%$ of samples were diluted with sterile double distilled water and standard serial dilutions were made in the order of $10^{-3}$, $10^{-4}, 10^{-5}, 10^{-6}$ and $10^{-7}$ (Cappuccino and Sherman, 1999). Total aerobic bacteria were enumerated on nutrient agar (Himedia) by the standard pour plate technique (APHA, 1995). Plates were incubated at $30^{\circ} \mathrm{C}$ for $24 \mathrm{~h}$ and the total number of bacteria was determined as colony forming units (CFU) and the plates were examined and growth characteristics noted. The isolated microorganisms were identified using standard methods (Collee et al., 1996).

\section{Disc diffusion method}

All the isolates tested for antimicrobial susceptibility against antimicrobial agents shown in Table-1 and 2. Antibiotic discs were obtained from Hi-media Ltd., Mumbai, India. The diameters of complete inhibition zone were measured and interpreted according to the chart provided by the manufacturers. 


\section{Phenotypic ESBL detection}

The antimicrobial discs and combination discs (cephotaxime $30 \mu \mathrm{g}$, ceftazidime $30 \mu \mathrm{g}$, cephotaxime $30 \mu \mathrm{g} /$ clavulanate $10 \mu \mathrm{g}$, and ceftazidime $30 \mu \mathrm{g}$ /clavulanate $10 \mu \mathrm{g}$ ) were placed on each plate; the plates were incubated at $30^{\circ} \mathrm{C}$ and were examined after 16-18 $\mathrm{h}$ of incubation. After 16-18 $\mathrm{h}$ of incubation, each plate was examined. The diameters of the inhibition zones were measured. An organism was interpreted as the ESBL producer (positive) if there was an increase of $\geq 5 \mathrm{~mm}$ in the inhibition zone of the combination disk when compared to the corresponding cephalosporin disk (CLSI, 2005).

\section{Results and Discussion}

Soil samples were collected from selected locations in and around Kanchipuram. Totally, six samples were collected using sterile polythene bags and transported to laboratory within two hours (Table 3). Bacterial examinations of collected soil samples were done employing serial dilution technique. The total number of bacteria was determined as colony forming units (CFU) (Table 4) and the plates were examined and growth characteristics noted. Poly-microbial nature of soil samples was observed. Totally 48 bacteria were isolated based on colony morphology. Out of 48 isolates, 21 (43.74\%) were gram positive organisms and $27(56.24 \%)$ were gram negative (Table 5). A standard microbial identification procedure (Collee et al., 1996) was used to characterise the isolated bacterial strains and the results were compared with Bergey's manual of systematic bacteriology (Holt et al., 1994).

All the isolates tested for antimicrobial susceptibility against antimicrobial agents shown in Table 6. The diameters of complete inhibition zone were measured and interpreted according to the chart provided by the manufacturers. Several studies have proved the importance of studying soil microorganisms and their associated resistance determinants as a strategy when it comes to addressing the problem of antibiotic resistance. All the gram positive bacteria showed resistant against Penicillin $G$ and Ampicillin. Except H3 strain, all the gram positive bacteria showed sensitivity to Ciprofloxacin. P1 showed resistant against Tetracycline and remaining all sensitive. All the gram negative bacteria showed sensitive to Amikacin, Gentamicin and Imipenem. H4, H6, V2, V7 and N12 strains showed resistant against Ceftazidime and remaining all exhibited intermediate and sensitivity results (Table 7).

Out of 27 gram negative organisms, 23 organisms showed ESBL positive based on phenotypic characterization (Table 8). This study clearly demonstrates the remarkable presence of pathogens bacteria in different samples which can be implicated into quantitative risk assessment. Our study over a short period raised significant data on the alarming development of resistance and the emergence of multidrug-resistant bacteria to antibiotics. Indeed all of the isolated bacterial strains have a significant increasing trend with multidrug resistance over time as a consequence of improper use of antibiotics. The testing for beta-lactamase reveal the presence of ESBL of penicillinase and carbapenemase in most organisms isolated.

The objective of this study was to isolate environmental bacteria from different contaminated niches in and around Kanchipuram. A motivation for this study was the numerous reports about the occurrence of pathogenic microorganisms in environmental wastes and the associated diseases (Yillia et al., 2008; Schraft and Watterworth, 2005; Germs and Coetzee, 2004; Carter et al., 2000). 
Table.1 List of antibiotics tested for gram-negative bacteria

\begin{tabular}{|l|c|c|}
\hline Antibiotics & Symbol & Disc Content \\
\hline Amikacin & $\mathrm{Ak}$ & $30 \mu \mathrm{g}$ \\
\hline Cefepime & $\mathrm{Cpm}$ & $30 \mu \mathrm{g}$ \\
\hline Ceftaridime & $\mathrm{Ca}$ & $30 \mu \mathrm{g}$ \\
\hline Gentamycin & $\mathrm{G}$ & $120 \mu \mathrm{g}$ \\
\hline Imipenem & $\mathrm{I}$ & $10 \mu \mathrm{g}$ \\
\hline
\end{tabular}

Table.2 List of antibiotics tested for gram-positive bacteria

\begin{tabular}{|l|l|l|}
\hline Antibiotics & Symbol & Disc Content \\
\hline Ampicillin & $\mathrm{A}$ & $\mathbf{1 0} \mathrm{\mu g}$ \\
\hline Ciprofloxacin & $\mathrm{Cf}$ & $\mathbf{5} \mathrm{\mu g}$ \\
\hline Pencillin G & $\mathrm{P}$ & $\mathbf{1 0}$ units \\
\hline Tetracycline & $\mathrm{T}$ & $\mathbf{3 0} \mathrm{\mu g}$ \\
\hline
\end{tabular}

Table.3 Selected sample collection site

\begin{tabular}{|c|c|c|c|c|c|}
\hline $\begin{array}{l}\text { S. } \\
\text { No }\end{array}$ & $\begin{array}{l}\text { Name of the Soil } \\
\text { Sample }\end{array}$ & $\begin{array}{l}\text { Date of } \\
\text { collection }\end{array}$ & $\begin{array}{l}\text { Time of } \\
\text { Collection }\end{array}$ & Name of the Location & $\begin{array}{l}\text { Geographic } \\
\text { location }\end{array}$ \\
\hline 1 & $\begin{array}{l}\text { House hold waste } \\
\text { dumping site }\end{array}$ & 12.02.2017 & 07:05 am & $\begin{array}{l}\text { Putheri, Near General } \\
\text { Hospital, Kanchipuram }\end{array}$ & $\begin{array}{l}\text { Lat: } 12.83355 \\
\text { Long: } 79.6848\end{array}$ \\
\hline 2 & $\begin{array}{l}\text { Vegetable Waste } \\
\text { dumping site }\end{array}$ & 12.02.2017 & $08.30 \mathrm{am}$ & $\begin{array}{l}\text { Railway Road (Rajaji } \\
\text { market), Kanchipuram }\end{array}$ & $\begin{array}{l}\text { Lat: } 12.82824 \\
\text { Long:79.70916 }\end{array}$ \\
\hline 3 & $\begin{array}{l}\text { Sewage Waste } \\
\text { running cannel }\end{array}$ & 12.02 .2017 & $08.03 \mathrm{am}$ & $\begin{array}{l}\text { Ennaikara Street, } \\
\text { Sheikpet, Kanchipuram }\end{array}$ & $\begin{array}{l}\text { Lat: } 12.83123 \\
\text { Long: } 79.70713\end{array}$ \\
\hline 4 & $\begin{array}{l}\text { Feather Dumping } \\
\text { Waste }\end{array}$ & 22.02 .2017 & $06.37 \mathrm{am}$ & $\begin{array}{l}\text { Melottivakkam, } \\
\text { Kanchipuram }\end{array}$ & $\begin{array}{l}\text { Lat: } 12.8391 \\
\text { Long:79.62792 }\end{array}$ \\
\hline 5 & Palar River Bed & 22.02.2017 & $07.15 \mathrm{am}$ & $\begin{array}{l}\text { River flyover bridge } \\
\text { near }\end{array}$ & $\begin{array}{l}\text { Lat: } 12.83367 \\
\text { Long: } 79.68215\end{array}$ \\
\hline 6 & $\begin{array}{l}\text { Narasamangalam } \\
\text { Hills }\end{array}$ & 22.02 .2017 & $10.10 \mathrm{am}$ & $\begin{array}{l}\text { Mamandur, Near By } \\
\text { Narasamangalam Hills }\end{array}$ & $\begin{array}{l}\text { Lat: } 12.74452 \\
\text { Long: } 79.66607\end{array}$ \\
\hline
\end{tabular}

Table.4 Total aerobic viable count of bacteria from collected soil samples

\begin{tabular}{|l|l|l|}
$\begin{array}{l}\text { S. } \\
\text { No }\end{array}$ & $\begin{array}{l}\text { Name of the Soil Sample } \\
\text { Cotal A erobic bacterial } \\
\text { Count (CFU) }\end{array}$ \\
\hline 1 & House hold waste dumping site & $65 \times 10^{-5} \mathrm{CFU} / \mathrm{gm}$ \\
\hline $\mathbf{2}$ & Vegetable Waste dumping site & $40 \times 10^{-6} \mathrm{CFU} / \mathrm{gm}$ \\
\hline 3 & Sewage Waste running cannel & $44 \times 10^{-3} \mathrm{CFU} / \mathrm{gm}$ \\
\hline 4 & Feather Dumping Waste & $56 \times 10^{-6} \mathrm{CFU} / \mathrm{gm}$ \\
\hline 5 & Palar River Bed & $98 \times 10^{-5} \mathrm{CFU} / \mathrm{gm}$ \\
\hline 6 & Narasamangalam Hills & $60 \times 10^{-5} \mathrm{CFU} / \mathrm{gm}$ \\
\hline
\end{tabular}


Table.5 List of aerobic bacteria isolated from the soil samples collected from in and around Kanchipuram

\section{Isolates}

\section{Gram positive (21)}

Coagulase negative Staphylococcus

Staphylococcus aureus

Enterococcus faecalis

Streptococcus pyogenes

Gram negative (27)

Enterobacteriaceae (22)

Klebsiella pneumoniae

Escherichia coli

Citrobacter freundii

Enterobacter aerogenes

Non-Enterobacteriaceae (5)

Pseudomonas aeruginosa

TOTAL

\section{Number of Strain}

\begin{tabular}{|c|}
\hline 11 \\
\hline 6 \\
\hline 3 \\
\hline 1
\end{tabular}

\begin{tabular}{|c|}
\hline 2 \\
\hline 12 \\
\hline 6 \\
2 \\
\hline \\
\hline 48 \\
\hline
\end{tabular}

Table.6 Antimicrobial susceptibility patterns of Gram Positive Bacteria

\begin{tabular}{|c|c|c|c|c|c|c|c|c|c|c|c|c|c|}
\hline \multirow{2}{*}{$\begin{array}{l}\text { S. } \\
\text { No }\end{array}$} & \multirow[t]{2}{*}{ Sample } & \multicolumn{3}{|c|}{ Penicillin G } & \multicolumn{3}{|c|}{ Ciprofloxacin } & \multicolumn{3}{|c|}{ Tetracycline } & \multicolumn{3}{|c|}{ Ampicillin } \\
\hline & & $\begin{array}{l}\mathrm{R} \\
18 \\
(\mathrm{~mm})\end{array}$ & $\begin{array}{l}\text { I } \\
20-27 \\
(\mathrm{~mm})\end{array}$ & $\begin{array}{l}\text { S } \\
29 \\
(\mathrm{~mm})\end{array}$ & $\begin{array}{l}\mathrm{R} \\
15 \\
(\mathrm{~mm})\end{array}$ & $\begin{array}{l}\text { I } \\
16-20 \\
(\mathrm{~mm})\end{array}$ & $\begin{array}{l}\mathrm{S} \\
21 \\
(\mathrm{~mm})\end{array}$ & $\begin{array}{l}\mathrm{R} \\
11 \\
(\mathrm{~mm})\end{array}$ & $\begin{array}{l}\text { I } \\
12-14 \\
(\mathrm{~mm})\end{array}$ & $\begin{array}{l}\mathrm{S} \\
15 \\
(\mathrm{~mm})\end{array}$ & $\begin{array}{l}\mathrm{R} \\
13 \\
(\mathrm{~mm})\end{array}$ & $\begin{array}{l}\text { I } \\
14-16 \\
(\mathrm{~mm})\end{array}$ & $\begin{array}{l}\mathrm{S} \\
17 \\
(\mathrm{~mm})\end{array}$ \\
\hline 1 & H1 & $\mathrm{R}$ & - & - & - & - & $\mathrm{S}-32$ & - & - & S-19 & $\mathrm{R}$ & - & - \\
\hline 2 & $\mathrm{H} 2$ & $\mathrm{R}$ & - & - & - & - & S-34 & - & - & S-21 & $\mathrm{R}$ & - & - \\
\hline 3 & H3 & $\mathrm{R}$ & - & - & - & $\mathrm{I}-20$ & - & - & - & S-25 & $\mathrm{R}$ & - & - \\
\hline 4 & H5 & $\mathrm{R}$ & - & - & - & - & S-28 & - & - & S-20 & $\mathrm{R}$ & - & - \\
\hline 5 & H7 & $\mathrm{R}$ & - & - & - & - & S-26 & - & - & S-20 & $\mathrm{R}$ & - & - \\
\hline 6 & $\mathrm{H} 8$ & $\mathrm{R}$ & - & - & - & - & S-27 & - & - & S-19 & $\mathrm{R}$ & - & - \\
\hline 7 & V1 & $\mathrm{R}$ & - & - & - & - & S-24 & - & - & S-17 & $\mathrm{R}$ & - & - \\
\hline 8 & V3 & $\mathrm{R}$ & - & - & - & - & S-27 & - & - & S-23 & $\mathrm{R}$ & - & - \\
\hline 9 & V4 & $\mathrm{R}$ & - & - & - & - & S-27 & - & - & S-17 & $\mathrm{R}$ & - & - \\
\hline 10 & V5 & $\mathrm{R}$ & - & - & - & - & $\mathrm{S}-23$ & - & - & S-16 & $\mathrm{R}$ & - & - \\
\hline 11 & V6 & $\mathrm{R}$ & - & - & - & - & S-26 & - & - & S-20 & $\mathrm{R}$ & - & - \\
\hline 12 & V10 & $\mathrm{R}$ & - & - & - & - & $\mathrm{S}-25$ & - & - & S-21 & $\mathrm{R}$ & - & - \\
\hline 13 & S3 & $\mathrm{R}$ & - & - & - & - & S-27 & - & - & S-22 & $\mathrm{R}$ & - & - \\
\hline 14 & F1 & $\mathrm{R}$ & - & - & - & - & S-29 & - & - & S-20 & $\mathrm{R}$ & - & - \\
\hline 15 & F2 & $\mathrm{R}$ & - & - & - & - & S-25 & - & - & S-18 & $\mathrm{R}$ & - & - \\
\hline 16 & P1 & $\mathrm{R}$ & - & - & - & - & S-37 & $\mathrm{R}$ & - & - & $\mathrm{R}$ & - & - \\
\hline 17 & P2 & $\mathrm{R}$ & - & - & - & - & S-37 & - & - & S-23 & $\mathrm{R}$ & - & - \\
\hline 18 & P3 & $\mathrm{R}$ & - & - & - & - & S-30 & - & - & S-19 & $\mathrm{R}$ & - & - \\
\hline 19 & P4 & $\mathrm{R}$ & - & - & - & - & S-38 & - & - & S-23 & $\mathrm{R}$ & - & - \\
\hline 20 & N4 & $\mathrm{R}$ & - & - & - & - & S-28 & - & - & S-24 & $\mathrm{R}$ & - & - \\
\hline 21 & N10 & $\mathrm{R}$ & - & - & - & - & S-32 & - & - & S-20 & $\mathrm{R}$ & - & - \\
\hline
\end{tabular}

R- Resistant, I - Intermediate, S-Sensitivity and $\mathrm{mm}$ - Millimeter in diameter. 
Table.7 Antimicrobial susceptibility patterns of Gram Negative Bacteria

\begin{tabular}{|c|c|c|c|c|c|c|c|c|c|c|c|c|c|c|c|c|}
\hline \multirow{2}{*}{$\begin{array}{l}\text { S. } \\
\text { NO }\end{array}$} & \multirow[t]{2}{*}{ Sample } & \multicolumn{3}{|c|}{ Amikacin } & \multicolumn{3}{|c|}{ Ceftazidime } & \multicolumn{3}{|c|}{ Cefixime } & \multicolumn{3}{|c|}{ Gentamicin } & \multicolumn{3}{|c|}{ Imipenem } \\
\hline & & $\begin{array}{l}\mathrm{R} \\
14 \\
(\mathrm{~mm})\end{array}$ & $\begin{array}{l}\text { I } \\
15- \\
16 \\
(\mathrm{~mm})\end{array}$ & $\begin{array}{l}\mathrm{S} \\
17 \\
(\mathrm{~mm})\end{array}$ & $\begin{array}{l}\mathrm{R} \\
14 \\
(\mathrm{~mm})\end{array}$ & $\begin{array}{l}\text { I } \\
15- \\
17 \\
(\mathrm{~mm})\end{array}$ & $\begin{array}{l}\mathrm{S} \\
18 \\
(\mathrm{~mm})\end{array}$ & \begin{tabular}{|l}
$\mathrm{R}$ \\
15 \\
$(\mathrm{~mm})$
\end{tabular} & $\begin{array}{l}\text { I } \\
16- \\
18 \\
(\mathrm{~mm})\end{array}$ & $\begin{array}{l}\mathrm{S} \\
19 \\
(\mathrm{~mm})\end{array}$ & $\begin{array}{l}\mathrm{R} \\
12 \\
(\mathrm{~mm})\end{array}$ & $\begin{array}{l}\mathrm{I} \\
13- \\
14 \\
(\mathrm{~mm})\end{array}$ & $\begin{array}{l}\mathrm{S} \\
15 \\
(\mathrm{~mm})\end{array}$ & $\begin{array}{l}\mathrm{R} \\
13 \\
(\mathrm{~mm})\end{array}$ & $\begin{array}{l}\text { I } \\
14- \\
15 \\
(\mathrm{~mm})\end{array}$ & $\begin{array}{l}\mathrm{S} \\
16 \\
(\mathrm{~mm})\end{array}$ \\
\hline 1 & H4 & - & - & S-21 & R-14 & - & - & - & - & S-27 & - & - & S-18 & - & - & S-32 \\
\hline 2 & H6 & - & - & S-21 & $\mathrm{R}-10$ & - & - & - & - & - & - & - & S-18 & - & - & S-30 \\
\hline 3 & V2 & - & - & S-21 & $\mathrm{R}-13$ & - & - & - & - & - & - & - & S-18 & - & - & S-31 \\
\hline 4 & V7 & - & - & S-21 & R-14 & - & - & - & - & - & - & - & S-18 & - & - & S-30 \\
\hline 5 & V8 & - & - & S-22 & - & I-16 & - & - & - & S-21 & - & - & S-19 & - & - & S-32 \\
\hline 6 & V9 & - & - & S-19 & - & - & S-22 & - & - & S-28 & - & - & S-17 & - & - & S-22 \\
\hline 7 & V11 & - & - & $\mathrm{S}-22$ & $\mathrm{R}-13$ & - & - & - & - & S-26 & - & - & S-19 & - & - & $\mathrm{S}-20$ \\
\hline 8 & V12 & - & - & S-24 & - & I-15 & - & - & - & S-27 & - & - & S-21 & - & - & S-27 \\
\hline 9 & S1 & - & - & S-21 & - & - & S-20 & - & - & S-28 & - & - & S-18 & - & - & S-23 \\
\hline 10 & S2 & - & - & S-23 & - & - & S-22 & - & - & S-20 & - & - & S-18 & - & - & S-30 \\
\hline 11 & S4 & - & - & S-27 & - & - & S-19 & $\mathrm{R}-10$ & - & - & - & - & S-22 & - & - & S-31 \\
\hline 12 & $\mathrm{~F} 3$ & - & - & S-20 & - & - & S-18 & - & - & - & - & - & S-18 & - & - & S-33 \\
\hline 13 & F4 & - & - & S-20 & - & - & S-18 & - & I-17 & - & - & - & S-19 & - & - & S-33 \\
\hline 14 & P5 & - & - & S-22 & - & - & - & - & - & - & - & - & S-21 & - & - & S-26 \\
\hline 15 & P6 & - & - & S-25 & - & - & - & - & - & - & - & - & $\mathrm{S}-23$ & - & - & S-28 \\
\hline 16 & P7 & - & - & S-24 & - & - & - & - & - & - & - & - & $\mathrm{S}-23$ & - & - & S-28 \\
\hline 17 & P8 & - & - & S-24 & - & - & - & - & - & - & - & - & S-24 & - & - & S-30 \\
\hline 18 & N1 & - & - & S-27 & - & I-17 & - & - & - & - & - & - & S-24 & - & - & S-35 \\
\hline 19 & N2 & - & - & S-25 & - & - & - & - & - & - & - & - & S-23 & - & - & S-28 \\
\hline 20 & N3 & - & - & S-24 & - & - & - & - & - & - & - & - & $\mathrm{S}-23$ & - & - & S-28 \\
\hline 21 & N5 & - & - & S-26 & - & - & S-19 & R-14 & - & - & - & - & S-25 & - & - & S-30 \\
\hline 22 & N6 & - & - & S-26 & - & - & - & - & - & - & - & - & S-24 & - & - & S-31 \\
\hline 23 & N7 & - & - & S-26 & - & - & - & - & - & - & - & - & S-24 & - & - & S-31 \\
\hline 24 & N8 & - & - & S-29 & - & $\mathrm{I}-15$ & - & - & - & - & - & - & S-27 & - & - & S-40 \\
\hline 25 & N9 & - & - & S-25 & - & I-17 & 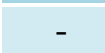 & R-10 & - & - & - & - & S-23 & - & - & S-31 \\
\hline 26 & N11 & - & - & S-27 & - & - & S-22 & R-13 & - & - & - & - & S-25 & - & - & S-32 \\
\hline 27 & N12 & - & - & S-27 & $\mathrm{R}$ & - & - & - & - & - & - & - & S-23 & - & - & S-40 \\
\hline
\end{tabular}

R- Resistant, I - Intermediate, S-Sensitivity and mm - Millimeter in diameter. 
Table.8 ESBL detection (Combined disc method)

\begin{tabular}{|c|c|c|c|c|c|}
\hline S.NO & Isolates & $\begin{array}{c}\text { CTX- } \\
\text { cefotaxidime } \\
(\mathbf{m m})\end{array}$ & $\begin{array}{c}\text { CEC- } \\
\text { ceftoxime }+ \\
\text { caluvanic } \\
\text { acid }(\mathbf{m m})\end{array}$ & $\begin{array}{l}\text { CAZ - } \\
\text { cefataxidime } \\
\quad(\mathrm{mm})\end{array}$ & $\begin{array}{c}\text { CAC- } \\
\text { cefataxidime } \\
+ \text { caluvanic acid } \\
(\mathbf{m m})\end{array}$ \\
\hline 1 & $\mathrm{H} 4$ & 12 & 16 & 11 & 18 \\
\hline 2 & H6 & 10 & 19 & 7 & 16 \\
\hline 3 & V2 & 16 & 16 & 8 & 20 \\
\hline 4 & V7 & 15 & 16 & 10 & 15 \\
\hline 5 & V8 & 17 & 17 & 12 & 18 \\
\hline 6 & F3 & 18 & 22 & 16 & 19 \\
\hline 7 & F4 & 23 & 23 & 20 & 21 \\
\hline 8 & N6 & 15 & 17 & 14 & 20 \\
\hline 9 & N7 & 13 & 11 & 12 & 17 \\
\hline 10 & N8 & 10 & 15 & 19 & 25 \\
\hline 11 & N9 & 16 & 20 & 16 & 20 \\
\hline 12 & V9 & 12 & 19 & 30 & 29 \\
\hline 13 & V11 & 10 & 17 & 17 & 24 \\
\hline 14 & V12 & 6 & 8 & 20 & 26 \\
\hline 15 & S1 & 4 & 12 & 13 & 16 \\
\hline 16 & S2 & 12 & 21 & 12 & 24 \\
\hline 17 & S4 & 18 & 23 & 12 & 32 \\
\hline 18 & P5 & 17 & 22 & 17 & 18 \\
\hline 19 & P6 & 14 & 24 & 13 & 22 \\
\hline 20 & P7 & 17 & 17 & 24 & 24 \\
\hline 21 & P8 & 21 & 13 & 11 & 20 \\
\hline 22 & N1 & 15 & 19 & 13 & 13 \\
\hline 23 & $\mathrm{~N} 2$ & 12 & 20 & 17 & 23 \\
\hline 24 & N3 & 11 & 22 & 20 & 24 \\
\hline 25 & N5 & 17 & 25 & 19 & 22 \\
\hline 26 & N11 & 20 & 16 & 13 & 18 \\
\hline 27 & N12 & 23 & 19 & 14 & 15 \\
\hline
\end{tabular}

$\mathrm{mm}$ - Millimeter in diameter.

Antibiotic usage and/or abuse in human and veterinary medicine, and the pharmaceutical industries as well as their release with human and animal wastes are closely connected with increased prevalence of antimicrobialresistant bacteria (AMRB). In addition to this, resistance of microorganisms to antibiotics of clinical interest has previously been reported in the area (Kinge and Mbewe, 2010).
The study demonstrated that 48 bacteria were isolated in collected soil samples analyzed which indicated the incidence of contamination as some of these species are indicators of faecal contamination and clinical waste. The soil may be a reservoir of larger pools of ARGs than ever imagined and various compartments like farmlands-water interphase, animal farm-surrounding 
interphase and sites where soil transport may occur due to rain run-off or animal movement may be critical for the occurrence of ARG and may be in focus for the assessment of their occurrence and further spread. Linking the environmental strains with clinic ones, promoted by human activities, might be a vital consideration (Heuer and Smalla, 2012; Gaze et al., 2011).

Benveniste et al., (1973) reported a known fact that various niches in the environment promote the emergence of AR as they contain pools of genes similar to ARGs in the hospital. In a study conducted by Rosenberg et al., (2016) soil may be a reservoir of larger pools of ARGs than ever imagined and various compartments like farmlands-water interphase, animal farm-surrounding interphase and sites where soil transport may occur due to rain run-off or animal movement may be critical for the occurrence of ARG and may be in focus for the assessment of their occurrence and further spread. Linking the environmental strains with clinic ones, promoted by human activities, might be a vital consideration.

During the last decades, the efforts on combating (multi)drug-resistant microorganisms were mainly focused on Gram-positive bacteria. This provided several potential novel antibiotics that, at least combined and prolonged in time, can still ensure efficacy of therapies. However, infections caused by Gram-negative bacteria are now becoming a more threatening problem mostly due to the lack of alternative treatments. The group of MDR nonfermeters causes particular concern within Gramnegative bacteria, since it represents the multi-drug resistance to the extreme.

The direct and indirect costs associated with antibiotic resistance; promote national coordination and development of action plans to respect the measures of hygiene, combat antibiotic resistance; promote the prudent use of antibiotics and the systematic implementation of infection control measures for the prevention and treatment for reduce morbidity, mortality. The use of antibiotics in human health and animal, including the impact on the food chain; review the teaching of prudent use of antibiotics in the faculties of medical sciences, veterinary and life, and implement effective policies.

This study clearly demonstrates the remarkable presence of antibiotic bacteria in different samples which can be implicated into quantitative risk assessment. Our study over a short period raised significant data on the alarming development of resistance and the emergence of multidrug-resistant bacteria to antibiotics. Indeed all of the isolated bacterial strains have a significant increasing trend with multidrug resistance over time as a consequence of improper use of antibiotics.

The testing for beta-lactamase reveal the presence of ESBL of penicillinase and carbapenemase in most organisms isolated. Health risks in the environment as well as careful compliance with the WHO guidelines on surveillance, rational antibiotic prescribing, and standard treatment guidelines for both community- and hospital-acquired infections will lead appreciably towards reducing the ever-rising threat of antibiotic resistance. Strategic steps related to assessment and management in various environmental reservoirs and niches assert collective reduction in the threat and prevent the emergence of more aggressive superbugs.

\section{Acknowledgment}

We acknowledge the Dr. K.R. Venkatesan, Principal, Sri Sankara Arts and Science College, Enathur, Kanchipurm for engorgement and support. 


\section{References}

Adegoke, A.A., Faleye, A.C., Singh, G., Stenström TA. 2016. Antibiotic Resistant Superbugs: Assessment of the Interrelationship of Occurrence in Clinical Settings and Environmental Niches. Molecules. 22(1).

Allen, H.K., Donato, J., Wang, H.H., CloudHansen, K.A., Davies, J., and Handelsman, 2010. J. Call of the wild: Antibiotic resistance genes in natural environments. Nat. Rev. Microbiol. 8, 251-259.

APHA, 1995. Standard methods for examination of wastewater. $16^{\text {th }}$. Ed. Am. Pub. Health. Assoc., Washington D.C.

Baquero, F., Martínez, J.L and Cantón, R., 2008. Antibiotics and antibiotic resistance in water environments. Curr. Opin. Biotechnol. 19, 260-265.

Benveniste, R., and Davies, J., 2017. Aminoglycoside antibiotic-inactivating enzymes in actinomycetes similar to those present in clinical isolates of antibiotic-resistant bacteria. Proc. Natl. Acad. Sci. USA 1973, 70, 2276-2280. Molecules 22, 2911 of 17.

Bush, K., 2013. The ABCD's of $\beta$-lactamase nomenclature. $\mathrm{J}$ Infect Chemother. 19(4):549-559.

Cappuccino, J.G., Sherman, N., 1999. Microbiology: A Laboratory Manual $\left(6^{\text {th }}\right.$ Edn $), \quad$ Pearson Education publication, Singapore.

Carter, J.T., Rice, E.W., Buchberger, S.G., and Lee Y., 2000. Relationships between levels of heterotrophic bacteria and water quality parameters in a drinking water distribution system. Water Research, vol. 34, no. 5, pp. 1495-1502.

CLSI, 2005. Methods for dilution antimicrobial susceptibility tests for bacteria that grow aerobically;
Approved Standard-Seventh Edition document M7-A7.

Collee, J.G., Marmion, B.P., and Fraser, A.G., Simmons A. 1996. Mackie and McCartney Practical Medical Microbiology. $14^{\text {th }}$ ed. ChurchillLivingstone.

Gaze, W.H., Zhang, L., Abdouslam, N.A., Hawkey, P.M., Calvo-Bado, L., Royle, J., Brown, H., Davis, S., Kay, P., and Boxall, A.B., 2011. Impacts of anthropogenic activity on the ecology of class 1 integrons and integronassociated genes in the environment. ISME J. 5, 1253-1261.

Germs, W., Coetzee, M.S., van Rensburg, L., and Maboeta, M. S., 2004. A preliminary assessment of the chemical and microbial water quality of the Chunies River-Limpopo. Water SA, vol. 30, no.2, pp. 267-272.

Heuer, H., and Smalla, K., 2012. Plasmids foster diversification and adaptation of bacterial populations in soil. FEMS Microbiol. Rev.36, 1083-1104.

Holt, J.G., Krieg, N.R., Sneath, P.H.A., Staley, J.T., and Williams, S.T., 1994. Bergey's Manual of Determinative Bacteriology (Vols 1-4), Williams and Wilkins, Baltimore, USA, pp 751.

Kinge, C.W., and Mbewe, M., 2010. Characterisation of Shigella species isolated from river catchments in the North West province of South Africa. South African Journal of Science, vol. 106, 11-12.

Rizzo, L., C. Manaia, C. Merlin, T. Schwartz, C.Dagot, M.C. Ploy, I. Michael, and Fatta-Kassinos, D. 2013. Urban wastewater treatment plants as hotspots for antibiotic resistant bacteria and genes spread into the environment: A review. Sci. Total Environ. 447, 345360.

Rosenberg, G., Steinberg, N., OppenheimerShaanan, N., Olender, T., Doron, S., 
Ben-Ari, J., Sirota-Madi, A., BloomAckermann, Z., and Kolodkin-Gal, I., 2016. The interspecies competition between Bacillus simplex and Bacillus subtilis and its impact on the evolution of biofilms. NPJ Biofilms Microbiomes 2,15027 .

Schraft, H. and Watterworth, L.A., 2005. Enumeration of heterotrophs, fecal coliforms and Escherichia coli in water: comparison of $3 \mathrm{M}$ Petrifilm plates with standard plating procedures. Journal of
Microbiological Methods, vol. 60, no. 3, pp. 335-342.

World Health organization (WHO). 2016. Antimicrobial resistance. Geneva, Switzerland, $3^{\text {rd }}$ edition, 2

Yillia, P.T., Kreuzinger, N., and Mathooko, J.M., 2008. The effect of instream activities on the Njoro River, Kenya. Part I: stream flow and chemical water quality. Physics and Chemistry of the Earth, vol. 33, no. 8-13, pp. 722-728.

\section{How to cite this article:}

Suresh G., P. Raghu, U. Prakash, T. Chitrikha Suresh, S. Kumaran, S. Bharathi, K. Selvendiran and Poonguzhali T. V. 2018. Screening of the Antibiotic Resistant Environmental Bacteria Isolated from Selected Niches in and Around Kanchipuram Town, India. Int.J.Curr.Microbiol.App.Sci. 7(06): 3665-3674. doi: https://doi.org/10.20546/ijcmas.2018.7065.430 